\title{
Choice and access to the best schools of Rio de Janeiro: a rite of passage
}

Rodrigo Rosistolato

Federal University of Rio de Janeiro

\begin{abstract}
Each year in the city of Rio de Janeiro a ritual takes place for selecting and distributing groups of pupils among schools providing the second phase of primary education. Called remanejamento or reallocation, this process involves school directors, education coordinators and the families of pupils. Since part of the process is protected by secrecy, complete access to the rite proved impossible. However it was possible to analyse what happens through the dialogues of the professionals involved and from the viewpoint of the family members who took part in the process. The article demonstrates that the transfer system tends to separate the pupils based on family background and the relations that their parents have to the networks of solidarity that connect families and the management body of the schools. These multiple belongings separate the pupils who will gain places at the best schools from those who will be enrolled in mid-level or low-quality schools.
\end{abstract}

Keywords: rituals, Republican schools, educational inequalities, school management, school choice.

\section{Resumo}

Todo o ano ocorre, na cidade do Rio de Janeiro, um ritual de seleção e distribuição de grupos de estudantes entre escolas de segundo segmento do ensino fundamental. Batizado como remanejamento, esse processo envolve diretores de escolas, coordenadorias de educação e familiares de estudantes. Por ser, em parte, secreto e protegido, não tivemos total acesso ao cerimonial, 
mas é possível analisá-lo com base nas falas dos profissionais envolvidos e no ponto de vista dos familiares que participaram do processo. Demonstraremos que o remanejamento tende a separar os estudantes com base em seu pertencimento familiar e no tipo de inserção que os pais possuem nos circuitos de solidariedade que envolvem famílias e corpo de gestão das escolas. Esses múltiplos pertencimentos separam os alunos que terão acesso às melhores escolas e aqueles que serão matriculados em escolas medianas ou de baixa qualidade.

Palavras-chave: rituais, escola republicana, desigualdades educacionais, gestão escolar, escolha escolar. 


\section{Choice and access to the best schools of Rio de Janeiro: a rite of passage}

Rodrigo Rosistolato

\section{1 - Introduction}

Imagine ${ }^{1}$ being the father or mother of a child who wants or needs to study in Rio de Janeiro city's public education system. Given that there are 1,008 schools and you need to choose just one, some criteria must be established to make this choice. Suppose that you opt for a school close enough to home to be able to take your child there, within a 15-minute walk. Depending on the particular region of the city concerned, you will still have an average of five schools available. Which to choose, though? That's the question! This article will describe the processes through which families choose schools for their children and try to get them places. We will demonstrate that these choices depend on their families' background and the degree to which their parents are related to the networks of solidarity that connect families and the management body of the schools.

Brazil has two educational systems that run in parallel: a public sector funded entirely by the state, and a private sector organized and run by educational establishments without access to public funds. Both systems are supervised by the Ministry of Education. In the case of the public system, municipal governments are responsible for managing and funding primary education, while state governments are responsible for secondary education. Both municipal and state governments may also receive funds from the federal government and are free to use these resources according to the demands of their education systems.

1 I have decided to use the discursive strategy employed by Malinowski (1980) with the aim of immersing the reader more directly in the dilemmas experienced by parents during the process of choosing schools for their children. 
The private system can only be classified as a system as such because it adheres to the regulations set by the Ministry of Education. These regulations mainly relate to the school curriculum and the organization of primary and secondary level teaching. Decisions on how funds are raised and managed are left to the schools themselves, which are also free to establish the fees for enrolment and their monthly rates. ${ }^{2}$ Hence the private schools form part of the system because they follow the same rules concerning the curriculum and the organization of the various stages of schooling, while remaining independent in terms of their financial administration.

The private system is smaller than the public system. In the city of Rio de Janeiro, the focus of this study, private sector establishments offering primary education cater for $26 \%$ of all students (Bartholo 2014). Differences exist between the two systems in terms of performance and repeating years. In private schools in $2013,3 \%$ of students repeated years during the first years of education and $8 \%$ during the final years. In public schools the rates were higher: $8.7 \%$ for the first years and $11.6 \%$ for the final years. These repetition rates meant that for each 100 students matriculated in municipal schools, approximately 18 are behind in their schooling by two or more years. ${ }^{3}$

This situation is not very different from the context described in 1991 by Costa Ribeiro. Educational policies aim to make educational opportunities more equal, Yet Brazil still has high grade repetition levels and consequently high levels of age/school year disparity. Given that Costa Ribeiro (1991) had already argued that, rather than contributing to the future progress of the children concerned, repeating a year only tends to lead to more repetition, it is sad to observe that almost a quarter of a century later the situation remains much the same.

When the families choose a school for their children, they first have to decide between the public and private systems. Those who, for various

\footnotetext{
This administration model differs from countries where school selection policies have been introduced with state funding. In South America, Chile opted for a mixed system involving public, private and subsidized private schools. The private subsidized schools receive public funds through a school voucher scheme. The number of vouchers received by a school corresponds to the number of students that it succeeds in attracting. In a nutshell: the families choose the schools and the government pays the matriculation and monthly fees. For a detailed debate on the school selection policy in Chile, see Elacqua (2012).
}

All the data is available in the school census and was compiled via the QEDU website (http://www.qedu.org.br/). 
motives, choose a public school are opting for a system with more grade repetition than the private educational system. This fact multiplies the challenges faced by parents since they need to select a school that can educate their children without failing them in subsequent years. There is also another challenge. Rio de Janeiro does not require pupils to be enrolled at schools close to their home, meaning that children can study at any one of the municipality's schools. However the schools differ widely in terms of performance and/or reputation.

Previous studies have shown that a school's reputation tends to converge with its performance, so that a school with a high performance will have a good reputation while low-performing schools tend to have a poor reputation. The convergence between these two forms of classification performance evaluated through large-scale assessments and school reputation - suggests that even without knowing the educational indicators for schools, the families can compare them, identifying and choosing the best schools from their neighbourhoods.

Costa (2008) explores some of the elements that contribute to a school's reputation. During fieldwork, the author heard a number of phrases that encapsulated ideas of municipal schools and their students. One of the students in the morning classes ${ }^{4}$ asked whether the research group would remain at the school to observe the afternoon classes too, adding that, were they to do so, they would see a different school since only favelados (favela dwellers) attended in the afternoon. This reveals the idea that a school with a good reputation is one that does not provide places to favelados, while one with a poor reputation 'only' receives favelados - the curiosity here being that the pupil was talking about the same school: the difference was between the students studying in the morning and afternoon classes.

In earlier research (Costa, Pires do Prado \& Rosistolato 2012; Rosistolato \& Pires do Prado 2012) we also discussed the families' views about what constituted a good school. Rather than focusing on the performance of schools in national assessments, the families considered a number of points related to the structure of the school - 'a clean,' 'organized' school with 'teachers who don't go absent' - and its moral order - 'strict,' 'disciplined' school

4 Almost all schools in Brazil offer classes in the morning and the afternoon. Those which offer a full day's tuition are a rarity. 
that 'keeps the pupils in line.' From the parents' point of view, the cleaner and better organized the school, with teachers who are seldom absent, the better its reputation. At the opposite end are the dirty schools, disorganized, with teachers who are always off work; these have a bad reputation.

This same set of classifications was also found by Encarnação (2007). She investigated two schools with divergent reputations. While the first was seen as a 'worthwhile school,' the second was identified as one 'made for delinquents.' Aside from the student intake, the main element differentiating the schools was the director. The director of the 'worthwhile school' was seen to be strict and serious-minded, 'an excellent professional,' which, in the view of the population, contributed to the school's good reputation.

We were able to observe two sets of classifications that define a school's reputation. On one hand, the contrast between tidiness and mess, cleanliness and dirt, discipline and lack of discipline. On the other, the existence of favelados and nonfavelados. In this second set of criteria, pupils with a particular profile - poorer and favela residents - are presented as a problem for the schools. The opposite-that the schools are a problem for the students-occurs to no one. No school is ever accused of forcing pupils to abandon it and/or be sent back a year. Here Encarnação (2007) provides an important insight into this phenomenon, suggesting that teachers - especially those from schools with a worse reputation - believe that the pupils lack the capacity to learn the subjects being taught to them. We can therefore deduce that schools that are convinced that their students cannot learn the curricula being taught will also have no problem in making them retake the year, placing the blame on the pupils themselves and/or their families.

This is the complex scenario in which parents have to choose schools for their children. If they can find and obtain a place at a school of good quality and reputation, they will increase the chances of their children having successful school careers. If not, their children will face the problems associated with a school expecting little from its pupils and the stigma attached to studying at a school with a poor reputation. As this article will show, in this supposedly universal and republican school system, some schools, considered islands of excellence, stand out and parents compete for places using all the capital - social and cultural - at their disposal. Some act exclusively as individuals or citizens, while others 
activate personal relations they may have established with members of the municipal administration.

In Rio de Janeiro, the process of choosing and accessing schools may take place more than once. Considering that the municipal educational system includes schools that teach just the first phase of primary education, ${ }^{5}$ the parents who choose these establishments for their child's initial years will have to change school when the child completes his or her fifth year.

In Rio de Janeiro this question is different since although access to a school place is guaranteed, it does not necessarily mean receiving a place at the school chosen as the family's first preference. Since the schools differ in performance and reputation, and parents know which are the best schools, families need to develop strategies in this highly competitive environment.

The first step in understanding this process - choice and access - was to obtain information on the administrative regulations concerning school matriculation in Rio de Janeiro. The second was to map the viewpoints of the people directly involved in this social situation. ${ }^{6}$ The research focused on families that needed to change their children's school in 2013. To find them, we used the topographical division made by the Municipal Education Office to select two areas of the city where we would try to make contact with the families. It was when we entered the field that we discovered the first signs of the existence of a virtual rite of passage (van Gennep, 1975), as the children involved move from a social position embedded in one school model to another position, corresponding to the final years of schooling. Even so, pupils play only a small part in the process since it is their parents and the directors of their original schools who decide the paths that they will take after completing the initial years of primary education.

This ritual is an 'administrative' process called remanejamento or 'reallocation.' As we pointed out above, all the children studying at schools teaching just the first phase of primary education have to change schools for the second phase. Formal rules exist for this transition and they should, in theory, be no more than bureaucratic. However, this process is transformed

5 The first phase of primary education corresponds to the first five years of school, and the second phase to the four final years. After completing the ninth year, the student completes his or her primary education.

6 Here our research worked with the concept of 'social situation' developed by Gluckman (2010). 
into a ritual because (i) differences in performance and reputation exist between schools, and (ii) the education administrations tend to classify schools as 'their own' rather than part of an educational system. As a result, school managers take this situation to mean that they can choose students based on criteria defined by each establishment and negotiated during the reallocation ritual. They also therefore treat the moment not merely as a bureaucratic procedure, but as a watershed moment in the life of the pupils.

Parental involvement is also relatively limited. The process is controlled by the school managers, who possess the information necessary for the ritual. The school directors talk to all the parents but do not follow the same set of rules. This specific fact seems to be one of the defining elements of this process. Two families may talk with the same managers, ask the very same questions, yet receive different replies. Everything depends on the kinds of view that the bureaucracy has of the parents that it deals with.

Consequently - and especially given the secrecy involved in these reallocation practices - I argue that the process can be conceived as a ritual insofar as an order exists that confers a sense of collective realization. These practices are conceived and organized for specific purposes and involve a certain degree of exceptionality when compared to the everyday world of schools and families. It is worth pointing out that this conception converges with the ideas advanced by Peirano (2003). Discussing the concept of ritual formulated by anthropologist Stanley Tambiah, Peirano argues that rites should not be rigidly defined at a moment prior to the ethnographic situation. Although theories of rituals can always be proposed, extraordinary social situations need to be observed and conceived through their concrete immersion in the logic orienting their execution and the effective actions of those individuals performing the rituals. This approach helps us to understand the reallocation process and to think of it as a school ritual the good school ritual.

My main argument is that the rationalized and bureaucratized structure of the Rio de Janeiro Municipal Education Department still depends on rituals that organize the relation between schools and the public that they serve. What I term the good school ritual enters into dialogue with the formally established rules. These are followed but the degree to which they are adhered to depends on the classifications of each student. Some 
pupils are transferred to the second phase schools under strict observance of legislation, while others take paths that mix bureaucratic rules and other forms of social navigation. In this sense we can say that although the choice of school is legally assured to the families, the possibility of making the choice a concrete reality depends on the family members' knowledge of the formal rules and their field of possibilities. In theory, everyone has the right to choose any school, but obtaining a desired place depends on knowledge of the formal and informal rules present in the good school ritual, as well as the networks of sociability in which the families are embedded.

The text is divided into three parts, aside from the introduction and conclusion. In the first, I describe the ways in which the research unfolded in the field and the methodology employed. Next I analyse preparations for the ritual. In the third part, I identify the place of persons and individuals ${ }^{7}$ in the rite. Finally, I emphasize the elements that reveal the non-conflictive coexistence of formal rules and individual strategies when choosing and accessing Rio de Janeiro's municipal schools.

Before we turn to the actual description, it should be stressed that I am proposing an anthropology of education that transcends the physical and symbolic boundaries of school institutions. I look to comprehend the networks of relationships constructed between families and the State when parents come together to define their children's school careers. The article demonstrates that parents are social agents who make use of their capital - social and cultural - in a complex negotiation that will eventually define the educational future of the pupil by determining the school to which he or she will be sent. I also point out that there are two types of families. The first kind interacts with agents of the State as an individual, or a citizen, while the second dialogues with them as a person, or a relational being. As we shall see, those who relate as persons face fewer difficulties in matriculating their children at schools with better performance levels and better reputations.

My use of the category person in opposition to the individual is inspired by DaMatta (1985), who argues that the relations between Brazilians and the State does not take the notion of the individual - or the citizen - as the ideal basic unit. On the contrary, these relations are oriented by relations

7 As discussed below, this opposition between persons and individuals is taken from DaMatta (1985). 
between persons, families, kinship groups and friends. The basic difference is that the individual needs to follow universal rules that apply to everyone, in any social space, irrespective of any relations that individuals may have between themselves. The person, or relational being, on the other hand navigates socially on the basis of the relations that he or she establishes and the social place occupied as an outcome of these relations. In the specific case of gaining places at municipal schools, universal rules exist that must be adhered to by all the families. In theory, matriculation should be a merely bureaucratic process, but since differences in performance and reputation exist between the schools, some schools are more disputed than others. This dispute is not resolved on the basis of democratic criteria only. It is at this moment that networks of relations are activated and that families with some kind of friendship or kinship relation with the agents from the municipal bureaucracy are seen as persons and tend to be favoured during the selection process and reallocation to the best schools.

According to DaMatta (1979), this shift from individual to person is enabled through a ritual of separation, announced by the question do you know who you are speaking to? Employed in situations where a conflict of interests emerges, this question allows that people who use to cease being treated on the basis of the universal rules established by the State and be seen instead as a special person to the point of being released from any universalist protocol. This amounts to a hierarchical logic that allows some Brazilians to do anything while others can do nothing, or almost nothing. The author describes social situations in which the demand do you know who you are speaking to? is used to prevent the universal rules from being utilized. The ritual use of this question enables people to skip waiting in queue, to park in prohibited spots without being fined and to access public services without complying with the bureaucracy.

The question can be asked by anyone in a superior social position to someone else. An army colonel resorts to it to stop a traffic warden from issuing him a fine; a doctor uses it to enter a hospital outside of visiting hours. Some people also use the same question but are not necessarily in a superior position. In these cases, they present their personal relations. Working for a known politician, for example, allows the employee to use do you know who you are speaking to? to say that he or she is employed by the politician and should therefore be treated with much the same kind of 
distinction as would be shown to the politician him or herself. There are also moments when do you know who you are speaking to? does not need to be used as an explicit demand, simply because all the social agents present already know who they are speaking to. This is the case of the situations described here.

It is important to stress that DaMatta (1979) argues that the sphere defined by the State's automatic and free services is oriented towards the impersonal character of legal decrees and formal regulations. The author cites education and healthcare as examples. I shall contend, however, that even in these cases the impersonal gives way to "do you know who you are speaking to?" since, in the case of education, although school places are available to everyone, hierarchies exist between the best and worst schools. This context creates spaces of dispute, which tends to be resolved through the use of personal relations. The latter relations allow some individuals to shift to the world of persons while others are treated exclusively on the basis of the existing universal rules. This is not a phenomenon solely related to the distribution of places in the best schools. We are analyzing a general phenomenon, which orients the relations established between Brazilians and the State. What I aim to show is how this ritual unfolds during the distribution of places in Rio's public schools.

\section{2 - Cases that are not a case}

Anthropological studies can be built on case studies. As Fonseca (1999) points out, however, in ethnographic work the maxim "each case has to be taken on its own merits" becomes meaningless. Anthropologists work with individual cases, but guided by the idea of engaging in a debate that encompasses general aspects of the phenomena under analysis. I paraphrase the author's argument in the title to this section since the methodology defined for the research behind this article was inspired by this overall principle.

Initially ${ }^{8}$ focusing on the perspectives of the parents and the relations established with other agents, we first defined the cases to be analysed in

8 The original research project was collective and was proposed by a team from the Educational Opportunities Research Laboratory (LaPOpE), including myself. 
detail and the questions to be explored with each family. The Rio de Janeiro prefecture is divided into seven subprefectures: North Zone, South Zone, East Zone, Greater Tijuca, Centre and Historical Centre, Ilha do Governador, Barra and Jacarepaguá. We conducted in-depth ethnographic research in two: the South Zone and the North Zone. The two regions considered in this study were chosen due to their different ranking in terms of socioeconomic level and school performance. As well as the socioeconomic differences, there are also symbolic classifications that identify the South Zone as the locus of Rio's middle class, where intellectual people are found with cosmopolitan worldviews and in search of social ascension and/or differentiation (Velho, 1973; 1999). By contrast, the North Zone would be a more traditional and less cosmopolitan area.

Geographical location of the researched areas - South Zone and North Zone ${ }^{9}$

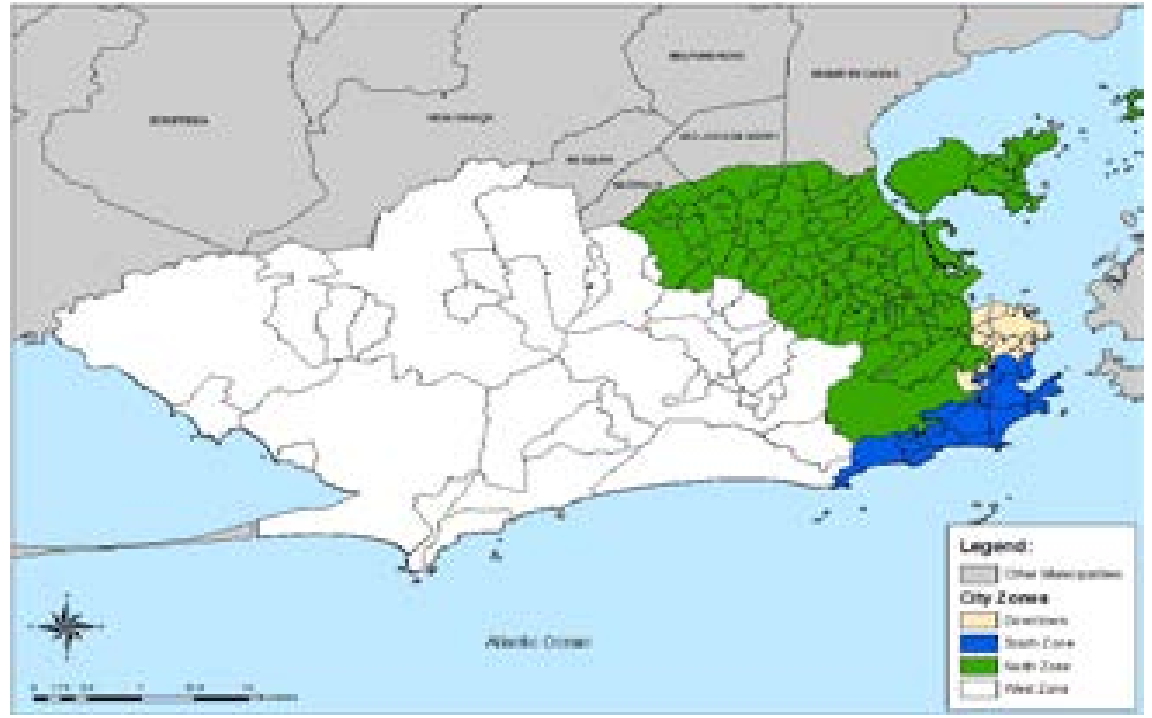

Neighborhoods researched at South Zone: Ipanema, Botafogo, Copacabana, Leblon e Leme. Neighborhoods researched at North Zone: Cordovil, Parada de Lucas e Brás de Pina.

At this point in the study, we realized that a macrosociological analysis of the set of schools from the municipal network would be needed in order for us to be able to select the locations for subsequent fieldwork. Here we 
benefitted from the direct collaboration of sociologists Marcio da Costa and Mariane Koslinski, who provided us with data on Rio de Janeiro's entire educational system and they selected pupils who were changing school during the school year that we wished to investigate: 2013. Based on this data, we selected two regions of the city - the South Zone and North Zone - and a matriculation pole ${ }^{10}$ in each region.

The performance differences between the schools in Portuguese language and mathematics can be measured by their results in the 'Prova Brasil' exam." The matriculation poles that we analysed are significant as they illustrate how the same educational system can contain very different schools. In the South Zone there is a degree of equilibrium in performance terms. In the North Zone, though, one school stands out while the others have much lower performance levels.

The South Zone pole is composed of 11 schools. Among these are five schools that offer both phases of primary education, five schools that offer just the first phase and one school that offers just the second phase. In terms of the reallocation process, this configuration means that there are five schools sending pupils and six receiving them. It is important to note that the pupils enrolled at the schools teaching both phases are not submitted to the reallocation procedure. This only happens when, for some reason, the parents wish to change the child's school. On the other hand, the pupils who study at schools teaching just the first phase will automatically have to change school.

The North Zone pole is also composed of 11 schools. These include three schools that offer both phases of primary education, six that offer just the first phase and two that offer just the second phase. In terms of the reallocation process, this configuration means that there are six schools sending pupils and five schools receiving them.

In order to build the profile of schools we used information on the grades offered at each and the variable mean obtained in the Standardized Brazil Exam (Prova Brasil Padronizada: PBP). The PBP mean refers to the years

10 "A matriculation pole [polos de matrícula] comprises a set of geographically proximate schools, constituting an organization with the purpose of allocating students during matriculation periods at the end of a school year" (Rosistolato, Pires do Prado, Koslinski, Carvalho and Moreira, 2014).

11 The National School Performance Assessment (Avaliação Nacional do Rendimento Escolar) popularly known as the Prova Brasil or Brazil Exam. 
2005, 2007, 2009 and 2011. This analysis allows us to rank the schools by performance so that the school referred to here as Escola Praça obtained the highest performance among those teaching the first phase of primary education in the North Zone pole. It is also the school with the best reputation, leading to a dispute for the places on offer. In the South Zone pole, the school with the highest performance will be referred to here as Escola Mar. Like Escola Praça, Escola Mar also has a positive reputation in the pole under analysis.

In this text, I present cases that summarize the dynamics of the good school ritual in Escola Praça. ${ }^{12}$ I made this choice because the pole in which it is inserted is also the most stratified. I describe four cases of families chose the school, of whom only two were successful.

Escola Mar is also included in the analysis later. During fieldwork we discovered that the ritual does not come to a conclusion when the children are enrolled. There is a moment that I classify as a post-ritual when the families go back to negotiate with the bureaucracy with the aim of transferring their children between schools. I describe the structure of this process at Escola Mar. Finally, I point out that although differences exist in the socioeconomic and cultural level between the South and North Zones of the city, the similarities between the two areas are clear when we consider the distribution of students within the municipal network.

\section{3 - Preparation for the ritual}

The fifth grade of school is a period of transition for primary school pupils in Rio de Janeiro. All pupils who passed the year will proceed to the final grades of primary education and enter school spaces quite different to those to which they have grown accustomed. One of the main changes relates to the number of teachers. The 'auntie' $(\mathrm{tia})^{13}$ will cease to exist and all the pupils will have various teachers who cannot be called uncles or aunts (tios). This symbolic shift is accompanied by other changes. These

\footnotetext{
12 In total, we analysed 52 cases.

13 During the first five years of primary education in Brazil, children have just one teacher (usually female). This teacher tends to be called 'aunt' (tia) by everyone: students, parents and the school management. This practice forms part of school culture. Unlike the teachers from the first phase, though, the usually male teachers working in the final years of primary school do not accept being called 'uncles/aunts' (tios).
} 
include the fact that children no longer queue to enter the classroom, the teachers cease looking at the children's exercise books, ${ }^{14}$ and each course has its own exercise book.

For the pupils who studied in schools offering just the first phase, another question surfaces: they will have to leave their primary schools. As well as all the changes inherent to this transition, they will have to go to a different school where they will be unfamiliar with the school life or the employees. Their destination will be decided in the good school ritual.

The ritual involves three main actors. The school directors - and the school management body - are responsible for the preparations for the ritual and for distributing information to the parents before the ritual itself takes place. The parents, in turn, may aim to be directly involved in the preparations to the ritual, but they will not have access to the final rites; they can only participate in the preliminary phase. Neophyte pupils have no control over what happens to them, unless their parents decided to get them involved. When this does occur, though, this involvement is minimal since the parents, at the very most, offer a list of schools and ask their child which he or she prefers.

Rigid rules apply during the ritual's preliminary phase. ${ }^{15}$ The work of Bruel (2014) analyses Rio de Janeiro municipality's matriculation policy. Specifically in relation to reallocation, the study indicates that even with rigid rules, space for negotiation between the State agents and the families exists. Each Regional Education Coordination Office (Coordenadoria Regional de Educação: CRE) has the autonomy to define whether the schools should ask the families to indicate the schools of preference or whether the institutions themselves (the schools of origin and the CREs) will define the schools to which the pupils will be sent. The author emphasizes that both situations are governed by the formal regulations for matriculation, but they produce distinct outcomes. While in the first case the parents have greater

14 One of the pedagogical practices of teachers during the first years of primary school is to check the students' notebooks. They set homework exercises and later 'mark' the work in the notebooks. This practice ceases in the final years of primary school. An interesting study of the use of notebooks in primary education can be found in Santos \& Souza (2005).

15 In the first phase, candidates who have siblings enrolled at the desired school; children of employees working at the desired school; adopted children supported by Municipal Law 2.210 of 21/07/1994; candidates coming from orphanages; parents with children enrolled at a school that offers education to youths and adults; children of teenage mothers and children of refugees with legal priority. Next, after catering for the students who fit these legal priorities, the places are distributed randomly. 
decision-making power over the school life of their children, in the second it is the educational bureaucracy that decides their educational future. Hence each director can be said to be able to apply the universal rules and deciding while orienting the families concerned. We talked to the parents who took part in the preliminary phase and they reported different rules, sometimes at the same schools with the same director.

The ultimate objective of the ritual is to transfer groups of students from those schools offering the five first grades to others that offer the four last grades. This process could be resolved by drawing names randomly. It would suffice to know the total number of children who need to be relocated and distribute them randomly among the schools. In this case, a child would be seen merely as an individual occupying a place at a public educational establishment. It goes without saying that the schools, in this case, would more than likely be much more diverse in terms of the pupils' racial and socioeconomic background and the cultural capital of the parents. Likewise, we would be unlikely to encounter flow patterns between schools from the same pole.

However, Carvalho's work (2014), using a quantitative approach, has shown that schools actually tend to be socially homogenous and that, in particular, there are flow patterns of pupils between schools belonging to the matriculation poles. Pupils who began their studies in low-performing schools tend to be reallocated to second phase schools that also have low performance. The same occurs with the high-performing schools. This reveals, then, that the distribution of pupils is not random, which allowed us to formulate one of the hypotheses informing the research behind this article. It was likely that the absence of any random allocation of students arose from the fact that some of the children and/or their families were not treated as individuals during the reallocation phase. Pupils treated as individuals would be reallocated on the basis of formal and universal rules, and would go to schools with either high or low performance. Those pupils treated as persons, on the other hand, would have guaranteed access to the best schools without needing to follow the universal rules rigidly.

Carvalho's work (2014) also analyses a set of interviews with school directors. One of the interviewees, who directs a high performance school of the second phase of primary education with a good reputation in the North 
Zone, reported that at the moment of reallocation he simply indicates the number of places on offer and allows the directors of the schools offering the first grades to decide how to proceed. He even remarked that he keeps quiet because the other directors would 'bite his hand' were he to interfere. He intervenes only when a director who has never used the places made available by his school asks for one. In this case, he understands that the request must concern a very good student and demands that the place in question is allocated to the director in question. The interviewee added that this seldom occurs, though, because in general the same school directors are responsible for filling the places that he offers.

The account given by this director allows us to perceive a relation between classification as a good student and a place to the best schools. It is not clear, however, what it means to be a good student, though it is possible to be certain about the position that the directors occupy in this ritual. It is the school directors of the second phase of primary education who offer places for those from the first phase to dispute and decide what to do with them. We also observed that the most disputed schools are unable to take in all the pupils who apply for them. Some pupils, therefore, will have to be transferred to other schools with lower performance levels and a worse reputation. Who will these pupils be? What criteria will be used by the directors when they take their decisions?

\section{4 - The Ritual}

\section{1 - Preliminary rites}

Parents have no knowledge of the ritual itself since their involvement is limited to the first phase. When we interviewed them, they offered accounts that allowed us to identify a number of elements related to the student selection processes that precede the meeting between school managers. We obtained accounts revealing that the directors do not treat the parents equally in accordance with strict procedures, which indicates the separation between individuals and persons in the perceptions of management professionals. Let us examine four cases that together synthesize the potential paths to a good school. 
Bianca ${ }^{16}$ is an 11-year old girl, white, Catholic, who lives in a favela in Rio de Janeiro's North Zone. She plays the violin and has been invited to perform at marriage ceremonies. Her mother lets her play, but does not allow her to receive any money for it. She realizes that any payment would constitute a work relationship, which could be provide the basis for a denunciation of child labour. As well as her love of music, Bianca also takes part in Maths Olympics at school. Her mother expects her to go on to a university education. Bianca has never repeated a year: she studies for two hours a day after school with the help of a private tutor.

Aline ${ }^{17}$ is a 12-year old pupil, parda (brown), ${ }^{18}$ non-religious, who lives in a district of the North Zone. She never studies when not at school and her mother anticipates that she will complete secondary school. Her mother evaluates her as an average pupil who repeated only one year.

Bianca's mother is single, black, Catholic, has a graduate degree in pedagogy and works at a private school. She did not worry about her daughter's move to a new school transfer because she knew that the ten children with the best marks at her first phase school would be transferred to the best school in the district, Escola Praça. This 'rule' is not established in any regulation. She says that her daughter always obtained grades of 9 and 10, which meant she was always confident about the second phase school. At the end of 2012 a meeting was held at the school and the director told them that the ten best students would be sent to Escola Praça.

Aline's mother is married, brown (parda), non-religious, completed her secondary education and works as a cleaner. She chose the school due to its reputation and because her sister was working there as a cook. We asked whether she was satisfied with the school and she replied yes, she was completely satisfied. Her case is curious because she did not even visit the school. She merely talked to her sister, who spoke to the director who then asked her to bring the documents needed to complete the matriculation. Hers is a significant case since she was at a low-performing school with a bad reputation and yet managed to get into Escola Praça.

\footnotetext{
16 All the names - of children, mothers and schools - are fictitious.

17 Aline's did not authorize recording of the interview.

18 Brazilian census data categories the population as white, black, indigenous, Oriental and brown [mixed 'race'] (branca, negra, indígena, oriental and parda.)
} 
Aline's success in moving from a low-performance school of poor repute to a high-performance school with a good name can be explained by the fact that her aunt worked at the desired school. In this case, she was not treated as an individual-she did not need to queue, fill out forms or take part in a random selection process. Her mother's role was to activate her kinship network and later complete her enrolment.

Bianca and Aline live in the same neighbourhood, though their socioeconomic level sets them apart. Aline resides in a house no asfalto - 'on the asphalt' or in the planned urban area of the city - while Bianca lives in the favela. Bianca's mother has a graduate degree and works as an educator at a private school. Aline's mother finished primary schooling and works as a cleaner. Neither of them receives any kind of government assistance. Though different, both girls ended up at Escola Praça, but for opposite reasons. Bianca was chosen due to her performance at the first phase primary school. Her mother commented that she was told her daughter would be sent to Escola Praça owing to her good grades. She also suggested that pupils are prepared for Escola Praça, as may be seen from this interview:

Interviewer: When did you start thinking about her transfer?

Bianca's Mother: No, no. She went because of her grades, because of her average grades.

Interviewer: She went because of her grades?

Mother: Yes!

Interviewer: So you didn't think about her transfer?

Mother: No, no. Thank God! Not me, because it would have been an ordeal for me, I wouldn't have known where to send her.

Interviewer: So what happens, how did you learn which school she's going to?

Mother: The school prepares [the children] and we quickly find out that the best pupils will go to Escola Praça. So as soon they enter here [the first phase 
school] they are being trained for the place! So they just studied the whole time to go to this school.

Interviewer: Ah, there's a kind of entrance course at the school, then?

Mother: Yes, because this school [Escola Praça] takes the best pupils from here for the sixth year. The sixth year, they select the best.

Interviewer: The best [pupils] from these schools here [in the region] will go to Escola Praça?

Mother: That's right!

Interviewer: So, there's a separate class there [at the first phase school] for those who'll do something like an entrance course?

Mother: No, it's not like that. There's the 4 th year and then the 5 th, and then in the 5 th year the mothers already learn what will happen. The highest ranking pupils will go to Escola Praça, I think there are 10 places, more or less, something like that. Because there's a limited number of places, the pupils have to be distributed and received from other schools.

Interviewer: Oh right. But what exactly was involved, because I have to ask you how you obtained the place she has today. What happened? A meeting..?

Mother: That's right, a meeting, the director said that the best pupils, the 10 best, would go to Escola Praça.

Mother: [Did you choose?] No, I didn't choose. She was nominated.

Aline's grades, on the other hand, were not so good and she had already been sent back a year once, but she was the niece of the school cook. As a result, all her mother had to do was go to the school with the documents needed to complete her matriculation. It can be noted that obtaining a place at the school was different in this case because while Aline's mother used her kinship networks, Bianca's path was determined by the director of the first phase school. Considering the dynamic of the good school ritual in this pole, 
it could be said that Bianca was chosen and backed by the director of her first phase school when the places were being distributed. Aline, on the other hand, was chosen because of her kinship relations and it was the director of the second phase school who backed her transfer. The mothers were content because they considered the school staff to be excellent.

It is impossible to tell whether the director used other criteria besides grades to select Bianca from among the other pupils with top grades. What interests us here is the comparison with Aline, who did not have good grades and was classified by her mother as an average pupil, with an average disciplinary record who does not study outside of school. During the interview, her mother, looking at her daughter, declared:

"I don't know what to do, she doesn't want to do anything with her life. She must think she's going to win the lottery or get a rich husband, because... it's so hard!"

Comparing the two cases, both could be said to have been treated as persons during the good school ritual and, consequently, had no problems obtaining a place at the desired school. Nonetheless, the distinct participation of the two families provides a curious contrast. Their destinations were, in some ways, preordained. The first because she had good grades and the second because she was the school cook's niece. In a sense, Aline had already won the 'lottery' that distributes places in the best schools because her aunt's presence ensured her 'ticket.'

\subsection{2 - The place of individuals in the Ritual}

On the other hand, there were some pupils who also chose the best school from the pole but were unable to obtain a place. Vanessa is an 11-year old girl, brown (parda), Catholic, who began to study at the age of three, studies two hours each day outside of school and never repeated a year. Her mother is 42 years old, single, brown (parda), Evangelical, and studied up to the end of secondary school. She earns some income from odd jobs and rates Vanessa as a good student. She stated that she has 'faith in God' that her daughter will complete her studies. We asked what would count as completing her studies and she said that it would mean getting a university degree.

Vanessa's mother began to worry about the change of school before her daughter had completed the first four grades in primary education. She has 
other children, who study at a local school with a worse reputation, but she wanted Vanessa to study at Escola Praça, because, she said, neighbours say really good things about the school. The teachers are said to be very good and the teaching at a high level. She therefore wanted to try it out and decided to enrol her daughter at the school. She went to the school, talked to the director and was given a form on which she had to choose up to five schools. She put Escola Praça as her top choice. She was then told that she would have to wait. She describes the event as follows:

Interviewer: - When did you learn that she would have to change school? When did you start thinking about changing her school?

Mother: - It was the same year that she was finishing the fourth year. At the start of the year the question came up: where were they going to send my daughter?

Interviewer: - At the beginning of 2012?

Interviewer: - So, you began thinking about [the move] at the start of 2012?

Mother: - Yes, back then.

Interviewer: - Is she at the school that you wanted for her? Did you try another school?

Mother: - I tried...

Interviewer: - Which?

Mother: - Yes... I can't recall the school's name. But a really good school...

Interviewer: - Escola Praça?

Mother: - No, not Escola Praça...

Interviewer: - Is it located here [in the North Zone district]? 
Mother: Yes, it is, only it's on the other side.

Interviewer: - Let me have a look at my list here...

Mother: - That's it, Escola Praça, that's it, I forget the name. It's Escola Praça... I think it's Escola Praça... what's the name of that school there, after the other one? Escola Praça? Ah, so yes, that's the one.

Interviewer: - That's definitely it?

Mother: - Yes.

Interviewer: - Escola Praça. So why were you unable to obtain a place there?

Mother: - Ah, because there... the selection is made by the city council, right, I think it's the closest school because, well, my son was there at another school and they placed him there, one of the criteria is that when you already have a child at the school, they more or less immediately decide to put the other child in the same school.

Interviewer: - And when this change took place, did the previous school show you any kind of document?

Mother: - Yes, they did.

Interviewer: - Did they say something about this school? What these schools are like?

Mother: - No, they just sent a paper with a choice, because they give 3 options of school for us to choose from, just that.

Interviewer: - So they didn't say anything about the school?

Mother: - They give you 3 options, and you're the one who decides.

Interviewer: - Do you remember which they were? 
Mother: - They were Escola Praça, [and two more schools] because they were really the closest... sending her faraway, you know...

When Vanessa's mother received the letter naming the school to which her daughter would be sent, she realized that her first choice had not been granted. Her daughter was set to be sent to another school. She did not challenge the decision because she also knew the school concerned and thought that it would be fine too:

Interviewer: - So you were allocated the second school. Did you ask why she wasn't sent to Escola Praça?

Mother: - No. In fact I was happy too with the option that they gave us, because my son was already studying there, and he would be able to accompany her going to school too and I've no complaints about the school.

Interviewer: - But when you said just now about the selection being made by the city council, how did you learn that?

Mother: - We send the options, right, and then we go to the school and the school communicates [the decision that] ...your child was transferred. Then it's the CRE, the city council, they're the ones who sort it out. So they put it all in the [computer] system, and the school options come out, where the places are...

From the moment that she accepted the school assigned to her daughter, she had no problems guaranteeing the place. She merely went to the school and completed Vanessa's matriculation.

José $^{19}$ is 12 years old, black, and neo-Pentecostal. He began to study when he was 4 years old and never repeated a year. His mother had previously tried to put him in a kindergarten but gave up because "he cried a lot." José always studied in the morning since, according to his mother: "in the morning his head is clearer, so I always try to place him in the morning intake." She thinks he is a good student since he has always got ' $\mathrm{B}$ ' grades. As for discipline, she classifies him as 'average' since he has been told off for talking a lot to other pupils during class. She thinks that he will continue his studies until the third year of secondary education.

19 Josés mother did not authorize recording of the interview. 
José's mother is 32 years old, single, black and neo-Pentecostal. She is unemployed and her last completed year of school was the fourth year of primary education. She has two children and receives the Family Allowance (Bolsa Familia ${ }^{20}$ ) and Rio Allowance (Bolsa Carioca ${ }^{21}$ ) for both. She was satisfied with the school where José completed the first years of primary education and did not want the boy to change school. However she understood that the transfer would be necessary because the school does not offer the second phase of primary education.

The year that José was due to complete the fifth year of primary education, his mother went to the school and filled in a form with three schools in order of preference. She chose Escola Praça as the first option because "they say that it's one of the best schools in the district." She wanted to try Escola Praça and thought it would be possible because she chose it as the first option. However, when she received the matriculation letter she learnt that José would have to be enrolled at another school. She even asked the director of Escola Praça the reasons why her son had not been accepted. The director replied that there were no places available and that "they had given first option to pupils who already had siblings studying at the school." When she learnt that other parents had also been unable to enrol their children at Escola Praça, she realized that there were indeed no more places left and did not challenge the decision contained in the matriculation letter.

We can note that Vanessa and José received the same treatment when they opted for Escola Praça. Both were treated as individuals, their parents filled in a form at the school and believed that their preferences would be guaranteed due to the formal nature of the matriculation process.

Bianca, Aline, Vanessa and José were completing the first phase of primary education, and wanted to continue their studies at the school classified as the best of the district - Escola Praça. For that reason, demand for places at this school was higher than supply. Given the democratic rules that, in theory, orient Brazil's education system, the best way for resolving the discrepancy between supply and demand would be a random draw. Those who were selected by lottery would transfer to Escola Praça and the others would be moved to other schools. This is not what happened. Bianca

\footnotetext{
20 Support offered by the Federal Government for poor families.

21 Support offered by the Municipal Government for poor families.
} 
and Aline obtained places at the school through their personal relations with members of the educational bureaucracy and school employees, while Vanessa and José were unsuccessful in securing a place because their parents adhered strictly to the formal procedures.

The cases described here suggest that the opposition between individuals and persons formulated by DaMatta (1985) still has a heuristic potential in terms of understanding the relations developed by Brazilians with the rules established by the Nation State. Its population continues to practice a contradictory synthesis of universal rules and personal relationships in spaces of dispute. Analysing the four cases, we can note that Aline's family made direct use of personal relations to ensure a place at Escola Praça. As a result, despite coming from the worst school in the district and being an average pupil in her mother's view, she gained a place at the best school in the second phase. The other three had different trajectories. Bianca also depended on her social networks since she was chosen and backed by the director of her original school during the good school ritual. She benefitted from the positive view of one member of the educational bureaucracy concerning her academic performance. Vanessa and José, by contrast, were not chosen by anyone and had to stick to the more universal rules present in the ritual.

According to Van Gennep: "It is the very fact of living which necessitates the successive passages from one special society to another and from one social situation to another so that an individual's life consists of a succession of stages whose end and beginning form general sets of a similar order: birth, social puberty, marriage, paternity, class progression, occupational specialization, and death. At each one of these general stages corresponds ceremonies whose object is identical: to facilitate an individual's passage from a determined situation to another situation just as determined" (Van Gennep 1978: 27).

The analysis of these cases expands our view of the ritual distribution of children between schools. Unlike traditional rituals where children leave their original identities and social relations behind when they enter the ritual, in the good school rituals the pupils are ranked on the basis of their social background, their performance at the first phase schools and/or their friendship and kinship relations. The relations between their families and members of the ritual and/or the view of an employee concerning the 
children seems to guide the paths taken by the students during and after the ritual. ${ }^{22}$

\section{2 - Liminal rites}

The two cases - Aline and Bianca - indicate that the procedures used in the ritual taken into account the capital - social and cultural - brought by the children. They are in a liminal situation, but their prior identities are not completely eclipsed. Having a relative who works at the best school in the district, or getting excellent grades, can act as marks of distinction that conduct the pupils during the ritual. At the same time, though, there are other pupils with excellent grades who are unable to obtain a place at the best school. Ultimately, it is the liminal rites - closed meetings between the schools who make up the poles, with or without the presence of representatives of the Regional Education Coordination Offices (CREs) - that decide the destination of the pupils. We did not receive permission to observe these liminal rites, though we were able to gain access to the narratives of the school managers concerning the process involved.

Carvalho's work (2014) analyses the practices undertaken in the reallocation process. She interviewed the directors of second phase primary schools - i.e. those that receive the transferred pupils - and discovered that their position in the ritual tends to be passive compared to the directors of the first phase schools. At the very beginning of the rite they state the number of places they can offer and the directors of the first phase schools then start to discuss how they will be filled.

The interviews also revealed that there are moments when the Regional Education Coordination Offices take part in the rites, limiting the room for manoeuvre of the first phase directors. In these cases, the school managers

22 During the research we also worked with the hypothesis that politicians influence the distribution of places at schools with the best reputations and performances. This hypothesis was constructed on the basis of one case - mapped at the start of fieldwork - in which a mother turned to a candidate for state deputy in order to obtain a place the school she wanted. The mother succeeded in gaining the place at the school through the politician's intervention. We failed to find any other case like this. It was described in Rosistolato \& Pires do Prado (2012). Based on the arguments proposed by Kuschnir (2000), it can be suggested that the impact of this kind of strategy should not be ignored. The author observed the everyday work of a local councillor and reports that requests for places at schools were frequent in these contexts. When they were solicited, the councillor, or one of her party supporters, entered into contact with the schools and asked for the places. The requests were always for those schools considered the best in the district. As part of our research, we undertook participant observation in the directorates of the schools throughout the matriculation period. We plan to able to discuss these hypotheses apropos these contexts at a later date. 
feel encroached upon because the central administration is deciding to legislate on a subject that, in their view, lies outside its remit. When this kind of intervention does not occur, the decision depends entirely on the debates taking place during the ritual.

The interviews indicated the disputes inherent to the ritual. Some directors like to fill all the places made available by the best second phase primary schools because they believe that their pupils are the best and should go to these establishments. Others divide their students between those who should be sent to the best schools and those who could be distributed to any school. It is important to stress that this division begins in the preliminary rituals, when they interact in diverging ways with the families wanting the most prestigious schools. We can argue that those who will gain a place are treated as persons while the others, though received too, are treated as individuals.

\section{3 - Post-liminal rites}

The next phase of the ritual is the matriculation of the students in the schools to which they were allocated. From this moment on they become recognized as second phase students and cease to be seen as children due to the autonomy granted after the ritual. There is, however, another kind of path that can be undertaken by families that are not satisfied with the schools to which their children were allocated.

At this moment, the parents return to the active position by seeking out and negotiating transfers for their children. In 2012, the most prestigious school that we analysed in the South Zone - Escola Mar - received 9 transferred pupils. Fernandes (2014) decided to investigate these pupils and managed to interview six of them. Almost all - five cases - were enrolled in the public system and decided to change school. The sixth case was that of a pupil from the private system who needed to migrate to the public system.

These cases illustrate the post-liminal rites because all of them were reassigned to the school after the official period of the good school ritual, and chose it because of its recognition as one of the best schools in the district, as well as having the best reputation within the matriculation pole. It was interesting to observe that all the families had access to the same employee when they began their move to gain a place at the best school 
from the pole. The families perceived him as someone responsible for a variety of posts at the school and contacted him via their personal relations. He is office worker at Escola Mar.

The employee himself was interviewed and described the entire process to be followed when the families decide to seek out a good school after the ritual. The first step at Escola Mar is, precisely, to talk to him. Although he is not the director, he presents himself as the best placed employee for resolving issues related to the matriculation of students outside the period. This occurs because the school director asks parents to see him in these cases. The employee's key position was confirmed by one of the interviewed mothers. She says that only this employee managed to solve the school's bureaucratic problems.

You can go there and ask just to see him, because he's the only one who will give you a concrete reply. He can tell you everything you need to know. Indeed people say that the office has 10 people working there, but the other 9 are just extras. ${ }^{23}$

The employee's reputation is recognized by all the families who matriculated their children after the good school ritual. He himself explains that the families seek him out directly and says that since he's 'a soft touch,' he understands the families' dilemmas and looks for places for them, even when these places do not officially exist. In these cases, he mobilizes a complex network involving staff from other schools and the Regional Education Coordination Office in which Escola Mar is located. These efforts are made as soon as the employee recognizes the mother asking for a place as a person who should obtain a place at that school. In these cases, he will even telephone the mother to tell her when the place is available.

The most interesting aspect is that the employee complains that as soon as they obtain the desired place, the families vanish and almost never come back to speak to him. On the rare occasion when they do return, they fail to give him the attention he thinks he deserves. This neglect from the families upsets him deeply since he thinks that the families should maintain the same kind of relationship with him.

All the matriculated families recognize the employee as the person responsible for getting them a place at the school. One of the mothers even

23 Interview conducted by Iris Fernandes on 23/09/2013. 
said that when she decided to change her son's school, she already knew about the employee "via the grapevine." People from her circuit of friends remarked "any problems, go to [name of the employee]," "if you want something done there [at Escola Mar], if you want a place, talk to [name of the employee] and he'll get one for you." These accounts show that although the parents do not go back to thank him as he would like, they contribute directly to constructing and maintaining his reputation in spaces outside the school. He is recognized as director, vice-director, pedagogical coordinator and employee of the school. In short: he is seen as the person who should be approached to obtain a place. As he himself explains, his approach allows him to live up to his reputation.

Felipo and Marina obtained a place at the school by going through the same employee. The account of their access strategies - undertaken after the matriculation period - allow us to perceive the type of relation that he established with the families who look for places at Escola Mar.

\subsection{1 - Felipo and the direct line to the 'vice-director'}

Felipo is 13 years old, brown (pardo) and an Evangelical from the Assembly of God Church. His mother sees him as a good student, since he "has a great capacity to learn, but sometimes he falters, if we don't push him, you know what it's like!' In terms of discipline, she says that he is average, because he is very lazy and does not study outside of school time. His mother thinks that he will go to university; she says that she will not let the same thing happen as occurred with his older brother, who left school and she did nothing about it. Since 2011, Felipo had been studying in the morning, but when he went to Escola Mar he entered the afternoon intake. His mother said that she did not know how this happened and at the end of the year she asked the 'vice-director' to move him to the morning intake. She said that a place became available and he switched her son without any problem. She praised the 'vice-director,' adding that "whatever we ask from him, he helps wherever possible." She said that although her son is at the school that she wanted for him, and she did not try another school, if she could, she would move him to a private school.

The interviewee stated that she did not consult anyone when it came to choosing Escola Mar. She already knew the 'vice-director,' because her older daughter had previously studied at the school. As for the process of 
choosing the school, she said "I always said that when he finished [the first phase of primary education] he would go to [Escola Mar]." The motive for her choice was that the school is good and is close to her place of work.

Rosana claimed that obtaining a place was not difficult. She said that she began to think about changing her son's school at the end of the year because the school where he was did not teach the second phase. As the school concerned was located in another matriculation pole, she said that her son was automatically transferred to a school from the same region, but she did not want this school under any circumstances. She said: "I didn't like the college's structure, inside or outside, I didn't like it...." The mother laughed at her own comments, adding: "he wasn't going to study there." To sort out the problem, she looked for a place at Escola Mar where she already knew the employee, and so "knew that there would be no problem." It was also located close to her work. She said that this was her first option "because she already knew about it": at other schools, she "would have to talk to the director," it would be harder work.

In January 2014 she went to Escola Mar, spoke to the employee and told him that she wanted a place, and "handed in the paperwork that the school requested and that was that." When we asked her to tell us how the obtained the place, she replied: "by knowing someone, if I didn't know anyone it would be more difficult." She added: "[the employee] is the vice-director, it's easier," and that, as cited earlier, "whatever we ask from him, he helps wherever possible." She said that he had first told her to transfer Felipo to Escola Mar back when he was in the first phase of primary education. He said: "send him here right away," but as he was already at a school in another pole, she waited to enrol him in the second phase.

\subsection{2 - Marina and the much-loved employee}

Marina is 12 years old, white and Catholic. Her mother, Samara, classifies her as a good student with average discipline. She has never repeated a year, she studies outside school three times a week, an hour per day, with the help of her brother or mother when she needs it. Samara thinks that her daughter will study up to university level.

Marina is an interesting case because her mother works at Escola Mar and she, by law, could request that her daughter be matriculated at the same school where she works. But at no point did she contemplate taking this 
course of action. She told us that her daughter studied at a school in another pole and was therefore automatically transferred to another school from the same pole. She enrolled her daughter because she did not want to lose the place and then went to the employee to resolve the issue.

When she talked to the employee, she said that her daughter was completing the first grades of primary education and he prepared a 'pre-matriculation' for her. We asked how this 'pre-matriculation' worked: she said that she did not know exactly, but he made it to guarantee her daughter's place. Afterwards the employee gave her a certificate and she took it back to the school to formalise the transfer. Her daughter did not even begin studies at the new school where she had been enrolled. Before classes began, she was transferred to Escola Mar. When asked whether it had been easy to get a place at Escola Mar, she said that the employee knows that "it's all a question of understanding based on necessity," since he is responsible for matriculation and "is very aware, [...], he sees the parent's need."

Asked about the response of the director to this, she said that "she doesn't even know." She related that the person who mostly talks to the parents is the employee, since "he knows everything": he is not on the school board, but he "knows everything about all the pupils," "he's more clued up on the children." When some situation occurs involving a teacher and a pupil, they always ask him to mediate, listen to both sides, since "without him the school doesn't function." He is "super human," a "really good person" who everyone at the school adores: there is not anyone who does not like him since he always helps whenever possible.

\section{5-Conclusion}

The good school ritual was discovered when we began fieldwork for a research project on school choice and access in Rio de Janeiro. Initially we thought that access to the schools would involve strictly bureaucratic procedures and that our goal would simply be to ascertain the selection criteria used by the schools. Fieldwork showed us that there was a series of far from bureaucratic processes coexisting alongside the rules established by the Rio de Janeiro Municipal Council for enrolling children in municipal schools. This type of dialogue between universalist rules and particularist interests is not found only in the distribution of school places. As DaMatta 
(1978) indicated, it comprises a structuring element of Brazilian society. In this article we demonstrate that it manifests in the educational field too.

From the moment when we decided to deepen our analyses, we found ourselves surrounded by a complex circuit of solidarity that both precedes and is sustained after the ritual we name the good school ritual. Here I have shown that parental involvement in this ritual is limited to the preliminary and post-liminal moments. The liminal moments themselves are restricted to the participation of managers from the first and second phase primary schools. They are the ones who in the end divide the pupils up between those who gain places at schools with a better reputation and performance, and others who will be sent to schools with a worse reputation and worse performance. The ritual therefore combines a series of procedures that collectively construct individual trajectories of school success or failure. Even if the pupils who went to the worse schools - in terms of reputation and performance - are successful, they will still receive a poorer education compared to the teaching offered to those chosen for the best schools.

These investigations have allowed us to broaden the debate on the correlation between socioeconomic level and school success because, as I show here, there are cases in which there are no significant differences in socioeconomic level yet even so the pupils follow distinct school careers within the same education system. Furthermore, the research also throws into question the common sense views suggesting that the population does not recognize the best schools. We found precisely the opposite. The interviewees recognize the best schools from their regions and want to enrol their children there. However, they also understand that not everyone will be able to get a place because the route to these schools is marked out and limited to those who recognize the maps providing access to the best schools.

To conclude, analysis of the good school ritual can be said to reveal the inequalities present in a public education system intended to be republican, but which is in fact stratified by school reputation and performance. In a sense, the ritual foments the idea that since the reallocation process is for everyone, it must also be democratic and egalitarian. The analyses described here show the exact opposite. It is a peculiar ritual since, even in 
the liminal phase, the neophytes are not equal because their background, their performance and their insertion in networks of solidarity contribute to their trajectories being more or less virtuous.

As argued at the start of the article, the rationalized and bureaucratized structure of the matriculation processes still depends on rituals that organize the relation between the schools and the public that they serve. This is the contribution offered here, along with the argument that the anthropology of education needs to transcend the physical and symbolic boundaries of school institutions to include the network of relations between persons and individuals who come together to define the trajectories of pupils who want or need to frequent public primary schools in Rio de Janeiro.

Received 21 November, 2014, approved 26 May, 2015

Translated by David Rodgers

Revised by Peter Fry

\section{Bibliography}

ALEGRE, Miquel Angel; BENTINO, Ricard. 2012. "The best school for my child? Positions, dispositions and inequalities in school choice in the city of Barcelona". British Journal of Sociology of Education, 33(6): 849871.

BALL, Stephen J.; VINCENT, Carol. 1998. "I heard it on the grapevine": 'hot knowledge and school choice". British Journal of Sociology of Education, Oxfordshire, 19(3): 377-400.

BARTHOLO, Tiago Lisboa. 2014. "Segregação escolar na rede municipal do Rio de Janeiro: análise da movimentação de estudantes”. Estudos em Avaliação Educacional, 25: 242-271.

BELL, Courtney A. 2005. "All choices created equal? How good parents select 'failing`schools". Downloaded 22 June, 2008, Working Paper, Columbia University, National Center for the Study of Privatization in Education. Disponível em: http:/|www.ncspe.org/publications_files/ OP106.pdf Acesso em: 02/09/2015 
BERENDS, Mark.; ZOTTOLA, Genevieve. 2009. "Social perspectives on school choice". In: M. Berends; M. G. Springer; D. Ballou; H. Walberg (orgs.), The handbook of research on school choice. New York: Routledge. pp. 35-54.

BRUEL, Ana Lorena. 2014. Distribuição de oportunidades educacionais: 0 programa de escolha da escola pela familia na rede municipal de ensino do Rio de Janeiro. Tese (Doutorado em Educação), Universidade Federal do Rio de Janeiro.

CARVALHO, Julia. Tavares. 2014. Segregação escolar e a burocracia educacional: uma análise da composição do alunado nas escolas municipais do Rio de Janeiro. Dissertação (Mestrado em Educação), Universidade Federal do Rio de Janeiro.

COSTA, Marcio. 2008. "Prestígio e hierarquia escolar: estudo de caso sobre diferenças entre escolas em uma rede municipal”. Revista Brasileira de Educação, 13(39): 455-469. ; KOSLINSKI, Mariane Campelo. 2011."Quase-mercado oculto: a disputa por escolas comuns no Rio de Janeiro". Cadernos de Pesquisa, 41(142): 246-266.

; PIRES DO PRADO, Ana; ROSISTOLATO, Rodrigo. 2012.

“Talvez se eu tivesse algum conhecimento...`: caminhos possíveis em um sistema educacional público e estratificado". Interseções, 14(1): 165192.

COSTA RIBEIRO, Sérgio. “A pedagogia da repetência”. 1991. Estudos Avançados,5(12): 07-21.

DAMATTA, Roberto. 1985. A casa \& a rua: espaço, cidadania, mulher e morte no Brasil. São Paulo: Brasiliense. - 1979. Carnavais, malandros e heróis: para uma sociologia do dilema Brasileiro. Rio de Janeiro. Zahar.

ELACQUA, Gregory. 2012. "The impact of school choice and public policy on segregation: Evidence from Chile". International Journal of Educational Development, 32(3): 444-453.

ENCARNAÇÃO, Marisa Santana da. 2007. Nem sucesso, nem fracasso: Uma abordagem etnográfica de uma escola. Dissertação (Mestrado em Ciências Sociais)Universidade Federal do Rio de Janeiro.

FERNANDES. Iris Medeiros Alves. 2014. “'É tudo uma questão de entendimento e necessidade "': uso de relações pessoais para acesso em 
uma escola da rede municipal do Rio de Janeiro. Trabalho de conclusão de curso (graduação em pedagogia), Universidade Federal do Rio de Janeiro.

FONSECA, Claudia. 1999. "Quando cada caso NÃO é um caso: pesquisa etnográfica e educação”. Revista Brasileira de Educação, 10: 58-78.

GLUCKMAN, Max. 2010."Análise de uma situação social na Zululândia Moderna". In: B. Feldman-Bianco (org.), Antropologia das sociedades contemporâneas. São Paulo: Editora UNESP: 227-305

KUSCHNIR, Karina. 2000. $O$ cotidiano da política. Rio de Janeiro: Jorge Zahar Editor.

MALINOWSKI, Bronislaw. 1980. "Objeto, método e alcance desta pesquisa”. In: Alba Zaluar Guimarães (ed.), Desvendando máscaras sociais. Rio de Janeiro: Francisco Alves Editora: 39-61

PEIRANO, Marisa. 2003. Rituais ontem e hoje. Rio de Janeiro: Jorge Zahar Editora.

RESENDE, Tania de Freitas; NOGUEIRA, Claudio Marques; NOGUEIRA, Maria Alice. 2011. "Escolha do estabelecimento de ensino e perfis familiares: uma faceta a mais das desigualdades escolares". Educação e Sociedade, 32(117): 953-970.

ROSISTOLATO, Rodrigo; PIRES DO PRADO, Ana. 2013. “Trajetórias escolares em um sistema educacional público e estratificado". In: XVI Encontro anual da Sociedade Brasileira de Sociologia [Brazilian Sociological Society]. Mimeo. . 2012. "Escolhas familiares e estratégias de acesso às escolas do sistema municipal de educação do Rio de Janeiro: navegação social em um espaço de disputa". In: Encontro Anual da ANPOCS [National Association of postgraduate Studies and Research in Social Sciences], 36, Águas de Lindóia. Mimeo.

.; KOSLINSKI, Mariane Campelo; CARVALHO, Julia Tavares; MOREIRA, Amanda Morganna. 2014. "Acesso às Escolas Públicas da Cidade do Rio de Janeiro: entre a demanda e a oferta". Anais do IV Colóquio LusoBrasileiro de Sociologia da Educação, 1: 269-287.

SANTOS, Anabela Almeida Costa; SOUZA, Marilene Proença Rebello de. 2005. "Cadernos escolares: como e o que se registra no contexto escolar?”. Psicologia Escolare Educacional, 9(2): 291-302. 
VAN GENNEP, Arnold. 1978. Os ritos de passagem. Petrópolis: Vozes.

VELHO, Gilberto. 1973. A utopia urbana: um estudo de antropologia social. Rio de janeiro: Zahar.

. 1999. "Os mundos de Copacabana". In: VELHO, Gilberto.

Antropologia urbana. Cultura e Sociedade no Brasil e em Portugal. Rio de Janeiro: Jorge Zahar Editor: 11-23.

Rodrigo Rosistolato

Federal University of Rio de Janeiro

rodrigo.rosistolato@gmail.com 